\title{
ANALYSIS OF THE EFFECTS OF SIX-MONTH STEP AEROBICS PROGRAMME WITH FEMALE STUDENTS WHO TRAIN AND FEMALE STUDENTS WHO DO NOT HAVE ORGANISED PHYSICAL TRAINING
}

\author{
Natalija Kurtović ${ }^{1}$, Nijaz Skender ${ }^{1}$, Naim Ćeleš ${ }^{1}$ and Adi Palić ${ }^{2}$ \\ ${ }^{1}$ Faculty of Pedagogy of the University of Bihac, Bosnia and Herzegovina \\ ${ }^{2}$ University Dzemal Bijedic in Mostar, Faculty of Teacher Education
}

Original scientific paper

\section{SUMMARY}

In a sample of 100 female students at the College of Nursing Studies of the University of Bihać, a six-months-long experiment was conducted with the aim of determining the differences between two groups, namely the one that practiced step aerobics twice a week and the other, control group, which had no organized physical training. The research topic is a longitudinal study on a sample of female students, through the prism of researching the efficiency of Step aerobics programme in the evaluation of selected anthropological characteristics, as well as through the process of valorization of this programme's effect on the anthropological status of female students compared to students who did not have an organized physical training. Based on t-test and discriminant analysis, it has been concluded that there are statistically significant differences between these two groups of students. The results show that there has been a change in the students of the experimental group in the initial and final measurement, which also reflected on the differences between the experimental and control groups. A single discriminant function that has very high statistical significance has been isolated. Based on these results, it can be confirmed that there was an improvement of results of morphological characteristics in female students, although they practiced only twice a week. It turned out that there was also a redistribution of body composition on account of improving the volume at the expense of adipose tissue.

Keywords: step aerobics, morphological characteristics 


\section{INTRODUCTION}

Aerobics is a unique sport phenomenon and it is among the sports which emerged in the last 25 years. It originated in America and began to spread from the late 1970s and was intended for all age groups, (women at first) and later to all others. With aerobic exercise, we aim to increase the abilities that are defined as aerobic fitness in modern sport (Sharkey, 1991) in terms of aerobic power and aerobic capacity as an indicator of the ability of taking, transporting and utilizing oxygen. Mastering certain motoric programmes plays very important role in aerobics. Nowadays, it is known that the management of movements implies constant "communication" between the CNS and the peripheral system to perform the movement, and it corrects the movement together with peripheral inlet, whereby CNS plans, programmes and sends command to limbs (Mirkov, 2011). In aerobics, there is an infinite number of elements of movement and their combinations (Zagorc, 1996). Most of previous research dealing with functional, motoric and morphological characteristics of female students (Skender, 2002), as well as the impact of certain aerobics programmes (Đug \&Mikić, 2007), are mostly about the positive impact of transformational programmes on a sample of subjects aged 19-21 years. Based on the presented results at the beginning and the end of the conducted fitness programme, i. e. step aerobics, over a period of two months with a frequency of 2 times a week, and on the basis of the importance of the changes which were tested with T-test, they concluded that the applied programme of step aerobics produced significant partial changes-effects- in a group of 21 students, when it comes to applied anthropometric variables. In a study, (Oreb, Blarežina \& Gošnik-Oreb, 1997) determined that after the implementation of the three-month aerobic dance programme within the Physical Education classes lasting two hours a week, there is an exceptional utility of aerobic dance especially in improving rhythm, movement frequency, explosive strength and coordination. Another study (Đug, Mikić \& Mačković, 2008) determined the level of tranformation processes of morphological characteristics as a result of the six-month programmed fitness among the students of first and second year, who attended the optional classes of fitness at the University of Tuzla. The research included 199 students at the age of 19-21. The TBC-total body condition fitness programme, which was conducted with another group of subjects, produced significant partial effects, namely the weight reduction and the reduction of subcutaneous adipose tissue, which is one of the main tasks of this fitness programme. Body structure (physique) is estimated so that the electrical signal passes more easily through the body parts that contain water (blood, urine, muscles) because they have better conductivity than through bones or adipose tissue. The greater the amount of non-adipose tissue, the greater conductivity and less resistance. Combining bioelectrical impedance with other factors such as height, weight, and age, we get information about the structure of body weight. (Nešić, Ostojić, Đokić \& Šeper, 2012). With this research, we tried to determine the effects of the Step aerobics programme, with the aim of transforming some anthropological characteristics in female students at the subsidiary faculty of the University of Bihać.

The subject of this research can be defined essentially as a longitudinal study on the population of female students, through the prism of researching the efficiency of Step aerobics programme in the evaluation of selected anthropological characteristics, as well as through the process of valorization of this programme's effect on the anthropological status of female students compared to students who did not have an organized physical training.

The main goal of this research is to determine the effects of a six-month Step aerobics programme in some anthropological characteristics among students of the University of Bihać. 
The secondary goal is to analyze the differences of effects of a six-month Step aerobics programme in some anthropological characteristics among female students of the University of Bihać and female students who did not have an organized physical exercise.

\section{METHODS}

The sample comprised of 100 students of the University of Bihać divided into two groups, one experimental and one control group. The experimental group (E), which followed the model of step aerobics, consisted of 50 students, and the control group (K) which was not subjected to an organized exercise programme, consisted of 50 students.

In studying anthropological characteristics of both groups' subjects, we used two batteries of tests to assess the following anthropological characteristics:

- AGE- Chronological Age

- AVIS- Body height- measured with Martin's anthropometer. A subject is on a firm, horizontal ground in an upright position. The head of the subject should be in such a position that the Frankfurt plane is horizontal. The subject straightens his/her back as far as possible, and puts feet together. The examiner stands on the subject's left side and makes sure that the anthropometer is placed directly along the back of the body and vertically, and then drops a metal ring - slider so that the horizontal plate reaches the patient's head. We read the result on the scale at the top part of triangular slot on the slider. The result is read with an accuracy of $0.1 \mathrm{~cm}$.

- AMAS- Body mass is measured with a scale placed on a horizontal, solid surface. The subject stands barefoot and calm at the middle of the scale, until the figure is formed on the scale. The result is read with an accuracy of $0.1 \mathrm{~kg}$.

- BMI- Body mass index - (estimated body weight) the ratio of height and weight

- BMR- Basal metabolic rate - the total energy that is released from the body to maintain the normal function of the motionless body such as respiration and circulation. (1kcal = $4.184 \mathrm{~kJ})$

- RESISTANCE- Impedance measures present physical resistance to electrical current. Muscle acts as a conductor of electricity, and adipose tissue acts as a resistor.

- FAT \% - a percentage of fat

- FAT MASS- a total mass of fat $(\mathrm{kg}, \mathrm{lb})$ in a body

- FFM-fat free mass. A mass of released fat composed of muscles, bones, tissue, water and other fat-free mass in the body.

- TBW - total body water. The total mass of water in the body is the amount of water expressed in $\mathrm{lb}, \mathrm{kg}$, or st.lb, which is found in the body. TBW makes from $50 \%$ to $70 \%$ of total body weight.

The sample of variables for assessing body composition were measured using body composition monitor model TANITA BC-540 has been used to measure body composition. This device, in the form of portable scales, uses installed software to measure the bioelectric impedance and body weight, and then, based on the measured data and the entered parameters (gender, age, body height) calculates the percentage of fat content in the structure of body composition, muscle mass in kilograms, a percentage of water in body structure, so called physical rating (on a scale 1-9), basal metabolic rate (BMR) in kilocalories and joules, metabolic age and weight of bones. 
In data processing, only three variables (the percentage of fat, muscle mass and percentage of water) are taken into consideration as the most important for research.

The sample of variables for evaluation of morphological characteristics: (Skender, 2008.)

AOBGRU - chest width

AOBNAD - scope of the upper arm

AOBTRB - scope of the stomach

AOBNAT - scope of the upper thigh

ANABTR - abdominal skinfold

ANABNAD - upper arm skinfold

ANAB - back skinfold

The following measuring instruments were used to anthropometric characteristics: Martin's anthropometer with precision scale of $0.1 \mathrm{~cm}, 1500$-milimeter-long Centimeter tape, caliper.

Measurements of morphological characteristics are measured according to the IBP (International Biological Program). The measurements were performed using a centimeter tape. Skin folds were measured with calipers. The measurements were performed in the morning in the initial and final measurements. The measurements were performed by the same measurer to reduce potential errors in the measurement to a minimum.

The measurement results were analyzed by the statistical programme SPSS 17. After checking the normality of distribution, it has been determined that the data have a normal distribution, and T-test and discriminant analysis have been made.

The subjects in the experimental group practiced Step aerobics programme which was full of aerobic exercises for at least 60 minutes, twice a week over a period of six months. The structure of movements in Step aerobics refers to the constant changes of rhythm and tempo as well as changes in energy consumption by using a stepper.

The subjects who practiced STEP aerobics programme performed the movements which consisted of numerous jumps, leaps, steps and turns which are connected into one entity in the form of choreography that looks like a modern dance, and after each choreography, they conducted shaping exercises that are performed for individual muscle groups.

\section{RESULTS}

Table 1. Descriptive statistics of all variables on initial measurement in both groups of respondents

\begin{tabular}{|c|c|c|c|c|c|}
\hline grupe & Varijable & $\mathrm{N}$ & Mean & SD & KS test \\
\hline \multirow{4}{*}{} & AVISTJ & 50 & 164,50 & 5,79 & 0,23 \\
\cline { 2 - 6 } & AMASTJ & 50 & 59.64 & 10,29 & 0,58 \\
\cline { 2 - 5 } & BMI & 50 & 21.78 & 3,83 & 0,19 \\
\cline { 2 - 5 } & BMR & 50 & 6049.68 & 426,42 & 0,26 \\
\cline { 2 - 5 } & OTPOR & 50 & 597.32 & 69,92 & 0,31 \\
\cline { 2 - 5 } & FAT\% & 50 & 15.53 & 7,46 & 0,87 \\
\cline { 2 - 6 } & FAT MASS & 50 & 44.09 & 3,25 & 0,40 \\
\cline { 2 - 6 } & FFM & 50 & 32.28 & 2,37 & 0,36 \\
\cline { 2 - 6 } & TBW & 50 & 84.97 & 6,48 & 0,39 \\
\cline { 2 - 6 } & AOBGRU & 50 & 24.48 & 2,91 & 0,54 \\
\cline { 2 - 6 } & AOBNAD & 50 & 74.37 & 8,34 & 0,28 \\
\cline { 2 - 6 } & AOBTRB & 50 & 50.80 & 4,71 & 0,65 \\
\cline { 2 - 6 } & AOBNAT & 50 & 1,76 & 0,61 & 0,91 \\
\hline
\end{tabular}




\begin{tabular}{|c|c|c|c|c|c|}
\hline \multirow{5}{*}{} & ANABTR & 50 & 1,58 & 0,48 & 0,32 \\
\cline { 2 - 6 } & ANABNAD & 50 & 1,20 & 0,52 & 0,12 \\
\cline { 2 - 6 } & ANABLE & 50 & 1,20 & 0,52 & 0,45 \\
\hline \multirow{4}{*}{} & AVISTJ & 50 & 164,32 & 5,06 & 0,28 \\
\cline { 2 - 6 } & AMASTJ & 50 & 61,17 & 10,05 & 0,65 \\
\cline { 2 - 6 } & BMI & 50 & 21,84 & 5,47 & 0,91 \\
\cline { 2 - 6 } & BMR & 50 & 6085,76 & 414,62 & 0,32 \\
\cline { 2 - 6 } & OTPOR & 50 & 572,38 & 106,82 & 0,12 \\
\cline { 2 - 6 } & FAT\% & 50 & 16,19 & 7,68 & 0,45 \\
\cline { 2 - 6 } & FAT MASS & 50 & 44,38 & 3,57 & 0,87 \\
\cline { 2 - 6 } & FFM & 50 & 32,48 & 2,60 & 0,40 \\
\cline { 2 - 6 } & TBW & 50 & 84,73 & 6,42 & 0,36 \\
\cline { 2 - 6 } & AOBGRU & 50 & 24,70 & 2,89 & 0,39 \\
\cline { 2 - 6 } & AOBNAD & 50 & 75,32 & 7,58 & 0,65 \\
\cline { 2 - 6 } & AOBTRB & 50 & 50,95 & 5,20 & 0,91 \\
\cline { 2 - 6 } & AOBNAT & 50 & 1,85 & 0,55 & 0,32 \\
\cline { 2 - 6 } & ANABTR & 50 & 1,57 & 0,47 & 0,12 \\
\cline { 2 - 6 } & ANABNAD & 50 & 1,28 & 0,59 & 0,45 \\
\cline { 2 - 6 } & ANABLE & 50 & 1,28 & 0,59 & 0,57 \\
\hline
\end{tabular}

Table 2. Descriptive statistics of all variables on the final measurement in both groups of respondents

\begin{tabular}{|c|c|c|c|c|c|}
\hline grupe & Varijable & $\mathrm{N}$ & Mean & SD & KS test \\
\hline \multirow{16}{*}{$\mathrm{E}$} & AVISTJ & 50 & 165,54 & 5,79 & 0,65 \\
\hline & AMASTJ & 50 & 59,81 & 10,88 & 0,91 \\
\hline & BMI & 50 & 20,60 & 4,21 & 0,32 \\
\hline & BMR & 50 & 5917,00 & 452,63 & 0,12 \\
\hline & OTPOR & 50 & 559,00 & 56,84 & 0,45 \\
\hline & FAT\% & 50 & 22,95 & 7,85 & 0,57 \\
\hline & FAT MASS & 50 & 44,15 & 3,48 & 0,12 \\
\hline & FFM & 50 & 32,35 & 2,55 & 0,45 \\
\hline & TBW & 50 & 86,10 & 6,89 & 0,28 \\
\hline & AOBGRU & 50 & 25,20 & 3,26 & 0,65 \\
\hline & AOBNAD & 50 & 68,00 & 6,86 & 0,91 \\
\hline & AOBTRB & 50 & 52,45 & 5,13 & 0,32 \\
\hline & AOBNAT & 50 & 1,54 & 0,64 & 0,12 \\
\hline & ANABTR & 50 & 1,54 & 0,64 & 0,45 \\
\hline & ANABNAD & 50 & 1,28 & 0,47 & 0,87 \\
\hline & ANABLE & 50 & 1,27 & 0,59 & 0,28 \\
\hline \multirow{13}{*}{ K } & AVISTJ & 50 & 164,32 & 5,06 & 0,65 \\
\hline & AMASTJ & 50 & 61,79 & 9,90 & 0,91 \\
\hline & BMI & 50 & 22,97 & 3,80 & 0,32 \\
\hline & BMR & 50 & 6109,46 & 407,30 & 0,12 \\
\hline & OTPOR & 50 & 543,06 & 64,53 & 0,45 \\
\hline & FAT\% & 50 & 25,32 & 6,69 & 0,12 \\
\hline & FAT MASS & 50 & 45,65 & 3,53 & 0,45 \\
\hline & FFM & 50 & 33,42 & 2,58 & 0,28 \\
\hline & TBW & 50 & 88,74 & 6,27 & 0,65 \\
\hline & AOBGRU & 50 & 26,48 & 3,34 & 0,91 \\
\hline & AOBNAD & 50 & 72,40 & 7,56 & 0,32 \\
\hline & AOBTRB & 50 & 54,26 & 5,23 & 0,12 \\
\hline & AOBNAT & 50 & 1,76 & 0,58 & 0,45 \\
\hline
\end{tabular}




\begin{tabular}{|l|l|l|l|l|l|}
\hline & ANABTR & 50 & 1,76 & 0,58 & 0,87 \\
\cline { 2 - 6 } & ANABNAD & 50 & 1,28 & 0,47 & 0,28 \\
\cline { 2 - 6 } & ANABLE & 50 & 1,27 & 0,59 & 0,65 \\
\hline
\end{tabular}

As part of this analysis, we determined statistical significances of differences of applied variables before and after the realization of the STEP programme. Table 3 shows the values of T- test of the dependent sample for determining statistical significance in morphologic characteristics and body composition. For a better understanding of the table, variables are marked in the different time points by adding the suffix I for the initial measurement at the end and the suffix $\mathrm{F}$ for the final measurement.

The analysis of Table 3 revealed statistically significant changes in the following variables of morphological characteristics: impedance, fat free mass, total body water, volume of the chest, volume of the upper arm, volume of the stomach, upper thigh and skin fold back.

Table 3.T-test in the area of morphological characteristics and body composition of the experimental group E2 in the initial and final measurement

\begin{tabular}{|c|c|c|c|c|c|c|c|c|}
\hline & \multirow[b]{2}{*}{ Mean } & \multirow{2}{*}{\begin{tabular}{|l|} 
Std. \\
Deviatic
\end{tabular}} & \multirow{2}{*}{ Std. Error } & \multicolumn{2}{|c|}{$95 \%$ Confidence Inte } & \multirow[b]{2}{*}{$\mathrm{t}$} & \multirow[b]{2}{*}{$\mathrm{df}$} & \multirow{2}{*}{$\begin{array}{l}\text { Sig. } \\
\text { (tail) }\end{array}$} \\
\hline & & & & Upper & Lower & & & \\
\hline AMASI - AMASF &,- 64898 & 2,38049 &, 34007 & $-1,33274$ &, 03478 & $-1,908$ & 48 & ,062 \\
\hline BMII - BMIF & $-1,1280$ & 4,42512 & 62581 & $-2,38560$ &, 12960 & $-1,802$ & 49 & 078 \\
\hline BMRI - BMRF & $-23,700$ & 99,9435 & 14,13415 & $-52,10363$ & 4,70363 & $-1,677$ & 49 &, 100 \\
\hline OTPORI- OTPORF & 29,3200 & 91,2170 & 12,90004 & 3,39640 & 55,24360 & 2,273 & 49 &, 027 \\
\hline FATPROI - FATPROF &, 67000 & 3,72626 & ,52697 &,- 38899 & 1,72899 & 1,271 & 49 & 210 \\
\hline FATMASI-FATMASF &,- 10200 & 2,65756 & 37584 &,- 85727 &, 65327 &,- 271 & 49 &, 787 \\
\hline FFMI-FFMF & $-1,2660$ & 1,17606 & , 16632 & $-1,60023$ &,- 93177 & $-7,612$ & 49 &, 000 \\
\hline TBWI - TBWF &,- 93600 &, 85589 & ,12104 & $-1,17924$ &,- 69276 & $-7,733$ & 49 &, 000 \\
\hline AOBGRUI - AOBGRUF & $-4,0100$ & 4,40682 & 62322 & $-5,26241$ & $-2,75759$ & $-6,434$ & 49 &, 000 \\
\hline AOBNADI - AOBNADF & $-1,7720$ & 1,40117 & 19816 & $-2,17021$ & $-1,37379$ & $-8,942$ & 49 &, 000 \\
\hline AOBTRBI-AOBTRBF & 2,91600 & 6,80952 & 96301 & ,98076 & 4,85124 & 3,028 & 49 & ,004 \\
\hline AOBNATI-AOBNATF & $-3,3100$ & 3,17749 &, 44936 & $-4,21303$ & $-2,40697$ & $-7,366$ & 49 &, 000 \\
\hline ANABTRI-ANABTRF &, 08800 & 46979 &, 06644 &,- 04551 & ,22151 & 1,325 & 49 & ,191 \\
\hline ANABNADI - ANABNADF &,- 03360 & ,33154 & ,04689 &,- 12782 &, 06062 &,- 717 & 49 & ,477 \\
\hline
\end{tabular}


Table 4. T-test in the area of morphological characteristics and body composition of the experimental and control group Initial measurement

\begin{tabular}{|c|c|c|c|c|c|c|c|c|}
\hline & Mean & $\begin{array}{l}\text { Std. } \\
\text { Dev }\end{array}$ & $\begin{array}{l}\text { Std. Err } \\
\text { Mean }\end{array}$ & $\begin{array}{l}95 \% \mathrm{Co} \\
\text { Inte. of }\end{array}$ & $\begin{array}{l}\text { nfid } \\
\text { the Dif. }\end{array}$ & $\mathrm{t}$ & $\mathrm{df}$ & $\begin{array}{l}\text { Sig. } \\
\text { (2-tai) }\end{array}$ \\
\hline AMAS & $-2,0606$ & 8,09297 & 1,40881 & $\mid-4,9302$ & ,80904 & $-1,463$ & 32 & ,153 \\
\hline BMI & $-1,12800$ & 4,42512 & ,62581 & $-2,3856$ & ,12960 & $-1,802$ & 49 & ,078 \\
\hline BMR & $-23,70000$ & 99,9435 & 14,13415 & $-52,103$ & 4,7036 & $-1,677$ & 49 &, 100 \\
\hline OTPOR & 1,73939 & 9,14730 & 1,59234 & $-1,504$ & 4,9828 & 1,092 & 32 & ,283 \\
\hline FATPRO & ,67000 & 3,72626 & ,52697 & -,38899 & 1,7289 & 1,271 & 49 & 210 \\
\hline FATMAS &,- 10200 & 2,65756 & ,37584 & $\mid-, 85727$ & ,65327 &,- 271 & 49 & ,787 \\
\hline FFM & $-1,12800$ & 4,42512 & ,62581 & $-2,3856$ & ,12960 & $-1,802$ & 49 & ,078 \\
\hline TBW & $-23,70000$ & 99,9435 & 14,13415 & $-52,103$ & 4,7036 & $-1,677$ & 49 & , 100 \\
\hline AOBGRU & 1,17879 & 4,23916 & ,73794 &,- 324 & 2,6819 & 1,597 & 32 & , 120 \\
\hline AOBNAD & 1,73939 & 9,14730 & 1,59234 & $-1,504$ & 4,9828 & 1,092 & 32 & ,283 \\
\hline AOBTRB & 1,17879 & 4,23916 & ,73794 &,- 324 & 2,6819 & 1,597 & 32 &, 120 \\
\hline AOBNAT & $-2,0606$ & 8,09297 & 1,40881 & $-4,9302$ & ,80904 & $-1,463$ & 32 & , 153 \\
\hline ANABTR & $-1,12800$ & 4,42512 & ,62581 & $-2,3856$ & , 12960 & $-1,802$ & 49 & ,078 \\
\hline ANABNAD & ,21121 & ,89753 & ,15624 &,- 1070 & ,5294 & 1,352 & 32 & , 186 \\
\hline ANABLE &,- 04152 & ,74377 & 12947 &,- 3052 & ,2222 &,- 321 & 32 & ,751 \\
\hline AMAS &,- 10200 & 2,65756 & ,37584 &,- 85727 & ,65327 &,- 271 & 49 & ,787 \\
\hline
\end{tabular}

Table 5 shows the differences between the experimental and control groups in the morphological characteristics and body composition. The values of the differences in the following variables have been determined: body weight, body mass index, basal metabolic rate, resistance, fat percentage, total weight of fat mass (in $\mathrm{kg}, \mathrm{lb}$ ) in a body, fat free mass, total body water, back skinfold, scope of the upper thigh, and abdomenal scope. 
The difference in morphological dimension of body weight is especially significant, with statistically significant difference of $0.5 \%$. If we analyze the variables of the body structure, the total weight of fat mass (in $\mathrm{kg}, \mathrm{lb}$ ) in a body and fat free mass, we see that they also showed statistically significant differences in these groups of subjects, especially because they are a part of body mass, as well as subcutaneous adipose tissue.

Table 5. T-test in the area of morphological characteristics and body composition of experimental and control groups

\begin{tabular}{|c|c|c|c|c|c|c|c|c|}
\hline & Mean & $\begin{array}{l}\text { Std. } \\
\text { Dev }\end{array}$ & $\begin{array}{l}\text { Std. Err } \\
\text { Mean }\end{array}$ & $\begin{array}{l}95 \% \mathrm{Co} \\
\text { Inte. of }\end{array}$ & $\begin{array}{l}\text { afid } \\
\text { the Dif. }\end{array}$ & $\mathrm{t}$ & $\mathrm{df}$ & $\begin{array}{l}\text { Sig. } \\
\text { (2-tai) }\end{array}$ \\
\hline AMASI - AMASF & $-2,0606$ & 8,09297 & 1,40881 & $-4,9302$ & 80904 & $-1,463$ & 32 & ,153 \\
\hline BMII - BMIF & 6,34242 & 12,38901 & 2,15665 & 1,9494 & 10,735 & 2,941 & 32 & ,006 \\
\hline BMRI - BMRF & 2,89697 & 4,26889 & ,74312 & 1,3832 & 4,4106 & 3,898 & 32 & ,000 \\
\hline OTPORI- OTPORF & 253,181 & 522,873 & 91,02064 & 67,778 & 438,58 & 2,782 & 32 & ,009 \\
\hline FATPROI - FATPROF & $-35,121$ & 91,64598 & 15,95352 & $-67,61$ & $-2,624$ & $-2,201$ & 32 &, 035 \\
\hline FATMASI-FATMASF & 4,80303 & 8,99908 & 1,56654 & 1,6121 & 7,9939 & 3,066 & 32 & ,004 \\
\hline FFMI-FFMF & 4,60606 & 8,40992 & 1,46398 & 1,6240 & 7,5880 & 3,146 & 32 & ,004 \\
\hline TBWI - TBWF & 1,77576 & 4,62264 & ,80470 & ,1366 & 3,4148 & 2,207 & 32 & ,035 \\
\hline AOBGRUI - AOBGRUF & 1,30000 & 3,39273 &, 59060 & ,0969 & 2,5030 & 2,201 & 32 & ,035 \\
\hline AOBNADI - AOBNADF & 1,73939 & 9,14730 & 1,59234 & $-1,504$ & 4,9828 & 1,092 & 32 & 283 \\
\hline AOBTRBI-AOBTRBF & 1,17879 & 4,23916 & ,73794 &,- 324 & 2,6819 & 1,597 & 32 & , 120 \\
\hline AOBNATI-AOBNATF & 5,02727 & 10,84811 & 1,88841 & 1,180 & 8,8738 & 2,662 & 32 & ,012 \\
\hline ANABTRI-ANABTRF & 2,79091 & 6,54529 & 1,13939 & ,470 & 5,1117 & 2,449 & 32 & ,020 \\
\hline ANABNADI - ANABNAD & ,21121 & 89753 & ,15624 &,- 1070 & ,5294 & 1,352 & 32 & , 186 \\
\hline ANABLEI-ANABLEF &,- 04152 &, 74377 & ,12947 &,- 3052 & 2222 &,- 321 & 32 & ,751 \\
\hline AMASI - AMASF & 20939 & ,57657 & 10037 & ,0049 & ,4138 & 2,086 & 32 & ,045 \\
\hline
\end{tabular}

In this subsection, we have analysed the quantitative morphological changes in the experimental group E (a group that practiced STEP aerobics) after completing six-month programme. Analysis of Table 3 shows that this area underwent quantitative changes. There has been a formation of an 
important discriminative function of height, .776 which indicates very high statistical significance of $0.01 \%$, a very high coefficient of significance.

Table 6. The significance of isolated discriminant functions of morphological characteristics and body composition in the experimental group's initial and final measurements

\begin{tabular}{|l|l|l|l|l|l|l|l|l|}
\hline Function & Eigenvalue & \% of Varia & Cumulative \% & Canonical & Wilks' Laml & & df & Sig. \\
\hline 1 & & & & Correlation & & Chi-squar & & \\
\hline
\end{tabular}

Table 7. The structure of discriminant function

\begin{tabular}{|l|l|}
\hline & 1 \\
\hline & 1 \\
\hline AOBNAT &, 255 \\
\hline AOBGRU &, 253 \\
\hline AOBNAD &, 227 \\
\hline OTPORI(a) &,- 205 \\
\hline AOBTRB &,- 155 \\
\hline FFM(a) &, 145 \\
\hline TBW &, 145 \\
\hline ANABLE &,- 116 \\
\hline AVIS(a) &,- 085 \\
\hline FATPRO(a) &,- 059 \\
\hline ANABNAD(a) &, 052 \\
\hline ANABTR(a) &, 042 \\
\hline FATMAS(a) &,- 034 \\
\hline AMAS &, 031 \\
\hline BMR(a) &, 027 \\
\hline BMI(a) &, 005 \\
\hline
\end{tabular}

Table 8. Centroids of groups

\begin{tabular}{|l|l|}
\hline group & Function \\
\cline { 2 - 2 } & 1 \\
\hline
\end{tabular}




\begin{tabular}{|l|l|}
\hline 1,00 & $-1,246$ \\
\hline 2,00 & 1,246 \\
\hline
\end{tabular}

This subsection analyzes the quantitative changes of morphological characteristics between the experimental group $\mathrm{E}$ and the control group $\mathrm{K}$ after completing the programme, keeping in mind that the experimental group completed a six-month programme of step aerobics while the control group did not have an organized physical exercise. The analysis of Table 9 indicates that morphological area in most subjects has undergone significant quantitative changes, as it was expected. We see that there has been the formation of an important function .633 which indicates the correlation between the set of data from which we conducted discriminant analysis and the discriminant function. The statistical significance of this canonical correlation is $0.01 \%$, indicating a very high bond.

Table 9. The significance of isolated discriminant functions

\begin{tabular}{|l|l|l|l|l|l|l|l|l|}
\hline Function & Eigenvalue & \% of Var & Cumulative Canonical & Wilks' La & & df & Sig. \\
\hline 1 &, $754(\mathrm{a})$ & 100,0 & 100,0 &, 656 &, 570 & 41,578 & 14 &, 000 \\
\hline
\end{tabular}

Table 10. The structure of discriminant function

\begin{tabular}{|l|l|}
\hline \multirow{2}{*}{} & Function \\
\cline { 2 - 2 } & 1 \\
\hline BMI &,- 441 \\
\hline FATMAS(a) &,- 434 \\
\hline FATPROC &,- 428 \\
\hline AMAS &,- 422 \\
\hline BMR &,- 404 \\
\hline AOBTRB &,- 348 \\
\hline FFM &,- 341 \\
\hline TBW(a) &,- 339 \\
\hline AOBNAT &,- 307 \\
\hline OTPOR &, 281 \\
\hline
\end{tabular}




\begin{tabular}{|l|l|}
\hline ANABLE &,- 269 \\
\hline ANABTR &,- 215 \\
\hline AOBNAD &,- 185 \\
\hline AOBGRU &,- 172 \\
\hline ANABNAT &, 118 \\
\hline AVIS &, 073 \\
\hline
\end{tabular}

Table 11.Centroids of group
\begin{tabular}{|l|l|}
\hline group & Function \\
\cline { 2 - 3 } & 1 \\
\hline 1,00 &,- 697 \\
\hline 2,00 & 1,056 \\
\hline
\end{tabular}

\section{DISCUSSION}

Considering the research results for the experimental group, it can be said that statistically significant differences have been achieved under the influence of the STEP programme, which is evident from Table 3 and 5. The achieved differences are significant in 8 variables of morphological characteristics and body composition. The analysis of Table 7 (the structure of discriminant function) shows that the tests of AOBNAT, AOBGRU and AOBNAD have the biggest contribution to the discriminant function. The subjects who practiced STEP aerobics programme in the experimental group performed the movements which consisted of numerous jumps, leaps, steps and turns which are connected into one entity in the form of choreography that looks like a modern dance, and after each choreography, they conducted shaping exercises that are performed for individual muscle groups. The effects of step workout are: strengthening the leg muscles and lower back, muscle tension and increasing the vitality of the entire organism. After analyzing the programme, we see that the subjects practiced for one hour 2 times a week. For these reasons, there have been significant changes of this morphological manifestation and the results of this discriminant function showed that the step programme statistically had a significant effect on improving the dimension of body volume, namely chest width, scope of upper thigh, and scope of upper arm. In Table 8 that shows the centroids of groups, it can be seen 
there is a clear polarization of results in the initial and final measurements, as well as in the previous group, only in lower intensity.

We can conclude that the programme has significantly influenced the redistribution of fat, voluminosity and scope of the skeleton, adiposity among the female students of the experimental group. The reason can be found in the programme performed by the students of the experimental group. The programme of Step aerobics that has been conducted twice a week for six months was full of aerobic exercise which lasted at least 60 minutes. The structure of the movement in Step aerobics refers to the constant changes of rhythm and tempo as well as changes in energy consumption by using a stepper. The subjects who practiced STEP aerobics programme performed the movements which consisted of numerous jumps, leaps, steps and turns which are connected into one entity in the form of choreography that looks like a modern dance, and after each choreography, they conducted shaping exercises that are performed for individual muscle groups. The effects of step workout are: strengthening the leg muscles and lower back, muscle tension and increasing the vitality of the entire organism.

Table 5 indicated there are statistically significant differences between the two groups (experimental and control). The discriminant analysis revealed one discriminant function that has a very high statistical significance.

The analysis of Table 10 which shows the structure of discriminant function, indicates that the variables AMASTJ, AOBTRB, AOBNAT, ANABLE i ANABTR gave the greatest contribution to discriminative function.

This is because movements in Step aerobics programme performed by the subjects in this experimental group significantly strained muscles of lower limbs, among other things, and the results are reflected in the back skinfold and abdominal skinfold. The movements performed in step aerobics significantly strain the muscles of the abdomen as in the various movements of vertical or horizontal climbing, stomach muscles play an important role and are continuously active. Of course the programme reflected on mass reduction in the experimental group, which is a direct result of the Step aerobics programme. This is to confirm that the Step aerobics programme, as aerobic exercise, significantly influenced on the reduction of mass and 
subcutaneous fat, as well as abdominal scope in the experimental group, which is the goal of aerobics. This observation is confirmed by the group centroids that show the difference in gender and large distance between groups. The control group did not have any organized programme, but we could not influence or control their free time completely. Yet, the results of discriminant analysis showed that these four variables made the greatest discrimination between these two groups.

Based on the results obtained in this study, we can confirm that the step aerobics had a very significant effect on the improvement of morphological characteristics among students of the University of Bihać. Although they practiced only twice a week, it turned out that a significant effect has been achieved in the majority of variables of the morphological area, and that the redistribution of body composition was performed with the aim of improving the volume at the expense of adipose tissue. The results in motor skills would probably show significantly better results, but unfortunately we did not research that in this paper.

\section{CONCLUSION}

Results we obtained in the research applied to a sample of 100 subjects of the student population at the University of Bihać speak in favor of the fact that step aerobics is very suitable form of activity and sport appropriate to this age. T-test indicated the difference between arithmetic means of the experimental and control groups in almost all the characteristics of morphological traits and body composition. The results of discriminant analysis indicate that one discriminant function of very high significance singled out. Also, analyzing the disparities between the initial and final measurements in the experimental group, it became apparent that the programme has caused significant statistical changes in the domain of most morphological characteristics and some variables of body structures. This speaks in favor of a claim that there has been a redistribution in body composition in favor of the creation of muscles in relation to the amount of fat, which was caused by the programme full of aerobic exercise, various kinds of jumps, leaps and steps. This study confirmed that step aerobics is a very important sport that should be practiced in student age.

Female students are burdened with lectures, classes and studying, which certainly reflects negatively on their morphological characteristics, and thus on the structure of the body composition, as well as on other anthropological characteristics. 


\section{REFERENCES}

Đug, M. \& Mikić, B., (2007): Uticaj step aerobika na transformaciju antropometrijskih karakteristika i motoričkih sposobnosti studenata. Sport u 21 vijeku, Sport Mont, 129-133.

Đug, M., Mikić, B. \& Mačković, S. (2008): Efekti transformacionih procesa antropoloških karakteristika studentica pod uticajem modelovanog programa aerobika. Zbornik apstrakata ,Ekologija, zdravlje, rad, sport“, (pp. 124-130). Banja Luka, BIH: Univerzitet u Banjoj Luci.

Mirkov, D. M. (2011): Motorička kontrola: Znanstveno područje, kratak pregled pojmova i metoda. In I. Jukić, C. Gregov, S. Šalaj, L. Milanović, T. Troš-Bobić i D. Bok (Ed.), Zbornik radova 9. Medjunarodna konferencija „Kondicijska priprema sportaša 2011“, (pp. 21-27), Zagreb, RH: Kineziološki fakultet Sveučilišta u Zagrebu, Udruga kondicionih trenera Hrvatske.

Nešić, N., Ostojić., S., Đokić, Z. \& Šeper, V. (2012): Razlike u regionalnoj mišićnoj distribuciji kod fudbalera. Tims Acta, 6(2), 43-56.

Oreb, G., Blarežina, Đ. \& Gošnik-Oreb, J. (1997): Utjecaj plesne aerobike na motoričke sposobnosti studentica. In D. Milanović (Ed.), 1. Međunarodna konferencija „Kineziologija - Sadašnjost i budućnost“ (pp 56-59), Zagreb, RH: Fakultetu za fizičku kulturu Sveučilišta u Zagrebu.

Skender, N., S. Kendić., M. Tabaković. \& N. Dujisić. (2002): Utjecaj nekih antropometrijskih parametara na motoričke sposobnsoti studentica Pedagoškog fakulteta Univerziteta u Bihaću. Homosportikus, (1/2), 113 - 117.

Skender, N. (2008). Transformacioni procesi antropoloških obilježja pod utjecajem posebnog kineziološkog programa. Bihać, BIH: Pedagoškli fakultet Bihać.

Sharkey, B.J. (1991): New dimensions in aerobic fitness. Champaing: Human Kinetics Books.

Zagorc, M. (1996): Klasifikacija nekih struktura pokreta u aerobici. Kineziologija, 28(1), 29 - 35.

Received: 23.06.2017. Accepted: 26.06.2017.

Correspondence author: Natalija Kurtović J.U. Pedagoški fakultet u Bihaću Luke Marjanovića b.b. 77000 Bihać tel: $037 / 229-850$ fax: $037 / 229-878$ natalijakurtovic@yahoo.com 